\title{
Water level-dependent morphological plasticity in Sagittaria montevidensis Cham. and Schl. (Alismataceae).
}

\author{
Demetrio, GR. ${ }^{a, b *}$, Barbosa, MEA. ${ }^{a, b}$ and Coelho, FF. ${ }^{b, c}$ \\ a Setor de Ecologia e Conservação, Programa de Pós Graduação em Ecologia Aplicada, Departamento de Biologia, \\ Universidade Federal de Lavras - UFLA, Campus Universitário, s/n, CP 3037, CEP 37200-000, Lavras, MG, Brazil

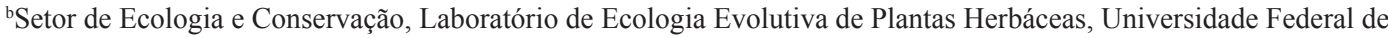 \\ Lavras - UFLA, Campus Universitário, s/n, CP 3037, CEP 37200-000, Lavras, MG, Brazil \\ 'Setor de Botânica, Departamento de Biologia, Universidade Federal de Lavras - UFLA, \\ Campus Universitário, s/n, CP 3037, CEP 37200-000, Lavras, MG, Brazil \\ *e-mail: gramosdemetrio@gmail.com; mario.eab@gmail.com; flaviafcoelho@gmail.com
}

Received: December 12, 2012 - Accepted: June 10, 2013 - Distributed: November 30, 2014 (With 7 figures)

\begin{abstract}
Aquatic plants are able to alter their morphology in response to environmental condition variation, such as water level fluctuations. The aim of this study was to evaluate the effect of water level on Sagittaria montevidensis morphology through measures of vegetative structures formed in drought and flood periods. We hypothesised that the plant height and the biomass of $S$. montevidensis leaves will increase during flood periods, while the biomass and diameter of petioles, and the basal plant area will increase during dry periods. We sampled a total amount of 270 individuals in nine sediment banks per visit, totalling 1080 plants. In order to compare plant morphology between dry and flood periods, we measured the water level in each bank and took the following variables for each plant: diameter, height and diameter of the biggest petiole. In order to compare biomass allocation between dry and flood periods, we sampled a total amount of 90 individuals in nine sediment banks per visit, totalling 360 plants. Plants were dried and weighed in the laboratory. All measured morphologic traits, as well as the biomass of leaf blades and petioles, were higher during flood periods, indicating that water level highly influences the morphology of S. montevidensis individuals. Our results suggest that these morphological responses allow survival and maintenance of $S$. montevidensis populations under environmental stress. These results can be linked to the invasive potential of $S$. montevidensis and sheds light on basic management practices that may be applied in the future.
\end{abstract}

Keywords: emergent macrophyte, drought, flood, water level, sediment banks.

\section{Plasticidade morfológica dependente do nível da água em Sagittaria montevidensis Cham. And Schl. (Alismataceae).}

\begin{abstract}
Resumo
As plantas aquáticas são capazes de alterar a sua morfologia em resposta a variações nas condições ambientais, tais como mudanças no nível da água. Nosso objetivo foi avaliar o efeito do nível da água na morfologia de Sagittaria montevidensis através de medidas de estruturas vegetativas formadas em períodos de seca e de cheia. Nós hipotetizamos que a altura dos indivíduos e a biomassa das folhas de $S$. montevidensis aumentarão durante períodos de cheia, enquanto a biomassa e diâmetro dos pecíolos, além da área basal da planta, aumentarão durante períodos de seca. Nós amostramos um total de 270 indivíduos, distribuídos em nove bancos de sedimento, por visita, totalizando 1080 plantas. Para comparar a morfologia das plantas entre os períodos de cheia e seca nós medimos o nível de água em cada banco e tomamos as seguintes medidas para cada planta: diâmetro, altura e diâmetro do maior pecíolo. Para comparar a alocação de biomassa entre os períodos de cheia e seca nós amostramos um total de 90 indivíduos em nove bancos de sedimento por visita, totalizando 360 plantas. As plantas foram secas em estufa e pesadas em laboratório. As plantas foram maiores no período de cheia e também apresentaram maior número e biomassa de folhas, maior diâmetro e biomassa de pecíolos e maiores áreas basais das rosetas. Nós concluímos que o nível da água influencia muito na morfologia de $S$. montevidensis. Nossos resultados sugerem que essas respostas morfológicas podem permitir a sobrevivência e manutenção de populações de S. montevidensis em estresse ambiental. Esses resultados podem ser ligados ao potencial invasivo de $S$. montevidensis e lançam luzes sobre práticas de manejo que poderão ser aplicadas no futuro.
\end{abstract}

Palavras-chave: macrófita emergente, seca, cheia, nível da água, bancos de sedimentos 


\section{Introduction}

Aquatic plants are particularly known for having great phenotypic plasticity, which can be defined as the organism's ability to alter its physiology or morphology in response to environmental variation (Schlichting, 1986). The production of locally adapted morphologies can arise as a result of phenotypic plasticity and is very important for plant persistence in sites with spatial and temporal heterogeneity (Alpert and Simms, 2002).

Plasticity in morphological traits can be decisive for plant survival, especially in the case of aquatic plants that can suffer submersion with the variation in water levels (Webb et al., 2012). Structures such as leaves and petioles can suffer changes in number, length, biomass and diameter in response to environmental variations, such as water level fluctuations (Cassol et al., 2008). Major key life-history traits that suffer morphological changes enhancing the survival of such plants include: tissues elongation, new leaves recruitment, petioles and basal plant diameters, and emergent surface area (Cooling et al., 2001; Deegan et al., 2007; Iwanaga and Yamamoto, 2008; Xie et al., 2008; $\mathrm{Li}$ et al., 2011). These morphologic adjustments lead to an elevation in the plants photosynthetically active organs above the water column, recovering contact with the atmosphere (Armstrong et al., 1994), enhancing plant survival and growth maintenance (Brandle, 1991). Biomass allocation patterns can also be modified during flood periods, and plants usually invest more in aerial parts when water level is increasing (Lowe et al., 2010; Chagas et al., 2012; Pan et al., 2012; Zhang et al., 2012; Tian et al., 2013).

Macrophytes belonging to the genus Sagittaria are common in wetland areas, such as coastal marshes (Baldwin and Mendelssohn, 1998; Martin and Shaffer, 2005) and freshwater environments (Pott and Pott, 2000; SánchezReyes et al., 2012). Many authors have studied the relationship between water level and morphology within the genus Sagittaria through laboratory and field experiments in natural areas, but none has addressed this issue in modified areas as reservoirs generated after dam construction. This is noteworthy because this kind of anthropogenic activity implies changes in natural hydrologic regimes of many freshwater systems worldwide (Dynesius and Nilsson, 1994; Tharme, 2003; Magilligan and Nislow, 2005; Aroviita and Hämäläinen, 2008). In this kind of modified area, the formation of sediment banks is common and may become a problem because, after their formation, the banks are rapidly colonised by macrophytes.

Studies dealing with plasticity in the genus Sagittaria have shown a consistent shoot elongation pattern (Wooten, 1986; Howard and Mendelssohn, 1995; Ookawara et al., 2005; Sánchez-Reyes et al., 2012) as well as a leaf blade area increase (Deegan et al., 2007) under flood conditions, but the behaviour of biomass allocation has not presented a unique answer in previous studies (Howard and Mendelssohn, 1995; Martin and Shaffer, 2005; Sánchez-Reyes et al., 2012). Despite the great number of studies concerning
Sagittaria species, scarce information is found about Sagittaria montevidensis morphological plasticity under different water regimes.

This species is well distributed in irrigated rice channels in southern Brazil (Pott and Pott, 2000). It is already documented that low levels of control may allow the increase in S. montevidensis population sizes to levels which may affect rice production (Gibson et al., 2001). Chemical control does not seem to be useful (Lima et al., 2010), and biological control is still poorly applied, since $S$. montevidensis showed high resistance levels (Pitt et al., 2004). Despite that fact, water regime is a central characteristic of habitat concerning the development of macrophytes and water level seems to be a determining factor controlling the development of emergent macrophytes (White and Ganf, 2002). So, water level fluctuations may represent a good alternative for macrophyte population management, but scarcely information is found about its effects on $S$. montevidensis. Laboratory studies by Cassol et al. (2008) showed that S. montevidensis presents morphologic changes under flood conditions. However, in that work, the maximum water level used in the treatments was $20 \mathrm{~cm}$ above ground, which may not cover a great range of water level fluctuations that occur in field conditions.

The aim of this study was to increase knowledge on the morphologic changes caused by water-level fluctuations and to evaluate how natural floods with higher flood amplitudes in an anthropised area would affect S. montevidensis morphology. Specifically we tested the following hypothesis: plant height and the biomass of $S$. montevidensis leaves will increase during flood periods, while the biomass and diameter of petioles, and the basal plant area will increase during dry periods.

\section{Material and Methods}

\subsection{Studied area}

Mortes River is part of the Mortes and Jacaré Rivers Basin, which is located in the mesoregion of Campo das Vertentes and covers an area of $10.547 \mathrm{~km}^{2}$. The area has a meso-thermal humid climate, with approximately six dry months a year (Figure 1). We carried out the study in a portion of Mortes River which is under the influence of the Funil power plant reservoir, between the following coordinates: $21^{\circ} 08^{\prime} 52^{\prime \prime} \mathrm{S}$; $44^{\circ} 52^{\prime} 36^{\prime \prime} \mathrm{W}$ and $21^{\circ} 07^{\prime} 56^{\prime \prime}$; $44^{\circ} 51^{\prime}$ '07' W (Figure 2). Sediment banks are formed in this portion of the river and many of them are exclusively colonised by $S$. montevidensis (Alismataceae), which were chosen for our study.

\subsection{Studied species}

Sagittaria montevidensis is a perennial emergent macrophyte with heights ranging from $0.5 \mathrm{~m}$ to $1.5 \mathrm{~m}$ (Lorenzi, 2000). It is morphologically characterised by its rosette habit of growing, with scapes bearing racemous inflorescences. The species occurs in marsh environments, in shallow lagoons and also in areas that have suffered modifications, like power plant reservoir 

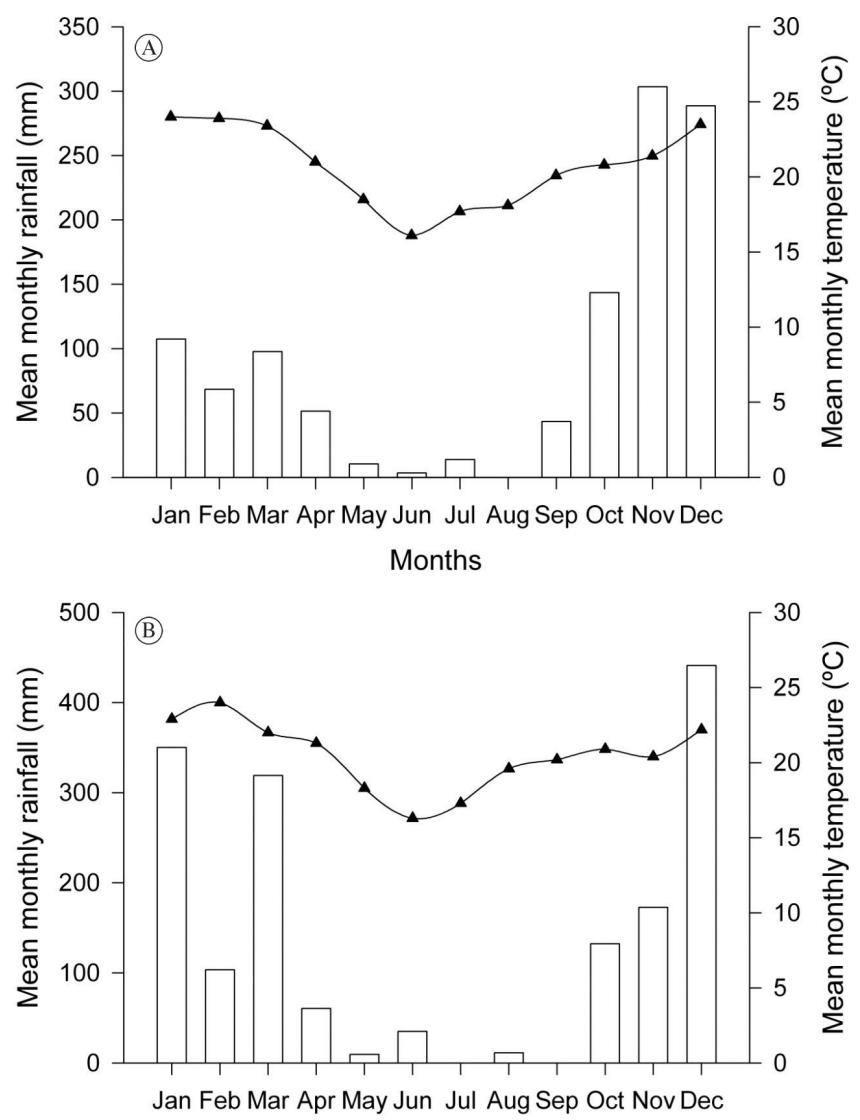

Months

Figure 1. Mean monthly rainfall (presented as bars) and mean monthly temperature (presented as the line pointed with triangles) of the study site in A) 2010 and B) 2011.
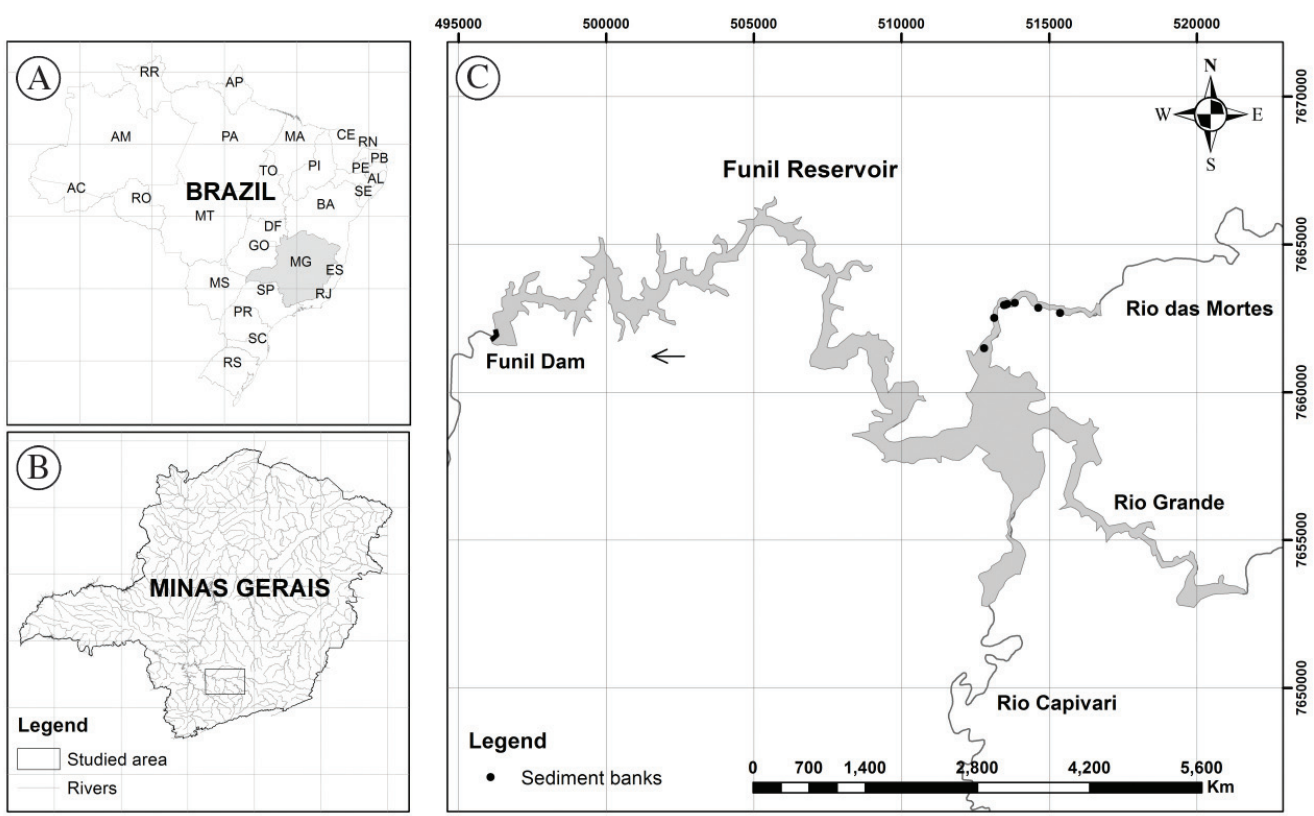

Figure 2. Sampled sediment banks in the occurrence area of $S$. montevidensis in the "Mortes" River portion under the influence of the Funil power plant reservoir, located in the south of Minas Gerais, Brazil. The Funil dam is presented as a solid line and the arrow represents the water flow direction. 
construction (Lorenzi, 2000; Pott and Pott, 2000). It is native to subtropical South America and has been introduced into Central and North America, Africa, Asia and Australia (Pott and Pott, 2000).

\subsection{Field sampling}

We sampled nine sediment banks which had been exclusively colonised by $S$. montevidensis rosettes. Sampled banks were marked based on their visual homogeneity regarding plant height. We sampled plants in an area of $30 \mathrm{~m}^{2}$ in each bank. We standardised this area in relation to the area of the smallest bank.

We conducted four visits to the sampling area from June 2010 to November 2011, during two cycles of dry and flood periods. Two visits were made during the first cycle (Drought 1, June 2010 and Flood 1, November 2010, hereafter called Period 1) and two visits in the second cycle (Drought 2, June 2011 and Flood 2, November, 2011 hereafter called Period 2). In each bank we sampled 30 plants per visit, representing a total amount of 270 plants per fieldtrip. We measured water level and took the following measures per plant: length and diameter of the highest petiole and basal diameter of the plant.

Biomass sampling occurred as follows: during the same time we performed the plant morphologic measurements, and using the same nine sediment banks as sampling areas, we collected 10 plants per bank, totalling 90 plants per visit. We took the plants to the laboratory and then separated leaf blades and petioles. The plant parts were dried at $60^{\circ} \mathrm{C}$ up to constant biomass and then weighed, in order to obtain the dry mass.

\subsection{Data analysis}

In order to test the water level effects on S. montevidensis morphology we first tested the distribution of each variable using Shapiro-Wilk tests. The homogeneity of variances was also tested using Levene's test. After these procedures, we compared plant height, diameter of the highest petiole, basal area of the plants, leaf blade biomass, and petiole biomass between drought and flood periods using t-Student tests. We used each sediment bank as a replicate and we sampled 30 plants for each bank. All statistical analyses were performed using the R statistical software (R Core Team, 2012).

\section{Results}

All response variables presented normal distribution $(p>0.05)$ and homogeneous variances $(p>0.05)$. The water level increased from $0 \mathrm{~cm}$ to $60 \mathrm{~cm}$ from June 2010 to November 2010 and from $0 \mathrm{~cm}$ to $160 \mathrm{~cm}$ from June 2011 to November 2011. The water level increase caused an increase in the total plants height, when comparing the first drought and flood cycle (Period 1) $(\mathrm{t}=106.42 ; \mathrm{p}<0.001)$ (Figure 3), and also when comparing the second drought and flood cycle (Period 2) $(\mathrm{t}=35.23 ; \mathrm{p}<0.001)$ (Figure 3 ), avoiding plant submersion. Besides the increase in petioles (mean of $20 \mathrm{~cm}$ ) between the first drought and flood cycle (Period 1), the highest and most significant increase (mean of $43 \mathrm{~cm}$ ) occurred between the second drought and flood cycle (Period 2), which presented a higher increase in water level (from $0 \mathrm{~cm}$ to $160 \mathrm{~cm}$ ).

Leaf blade biomass was significantly higher in flood periods when comparing the first drought and flood cycle $(\mathrm{t}=33.81 ; \mathrm{p}<0.001)$ (Figure 4), as well as in the second drought and flood cycle $(\mathrm{t}=37.83 ; \mathrm{p}<0.001)$ (Figure 4), indicating that $S$. montevidensis individuals produce larger leaves during flood periods.

Petiole diameter was also significantly higher in flood periods when comparing the first drought and flood cycle (Period 1) $(\mathrm{t}=146.29 ; \mathrm{p}<0.001)$ (Figure 5), and when comparing the second drought and flood cycle (Period 2) $(t=125.50 ; p<0.001)$ (Figure 5). The same occurred with petiole biomass, which was significantly higher in flood periods, when comparing the first drought and flood cycle (Period 1) $(\mathrm{t}=31.97 ; \mathrm{p}<0.001)($ Figure 6$)$, and also when comparing the second drought and flood cycle (Period 2)

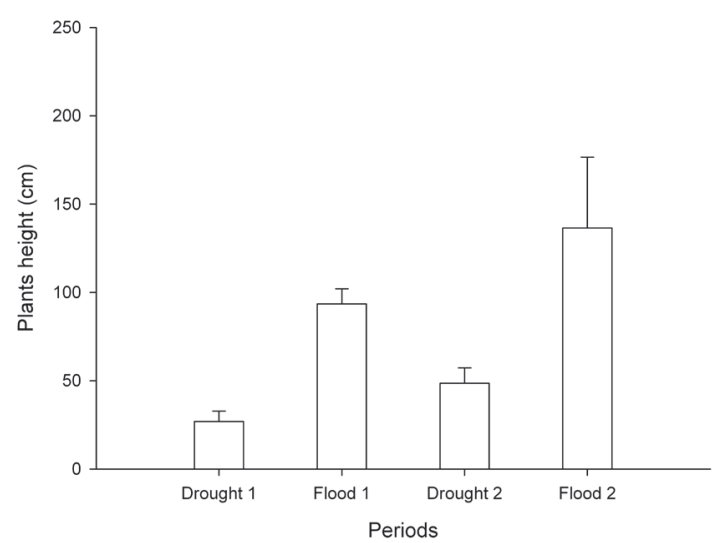

Figure 3. Plant height during flood and drought periods in the Funil power plant reservoir. The plants were higher during both sampled flood periods, showing a growth pattern during these times.

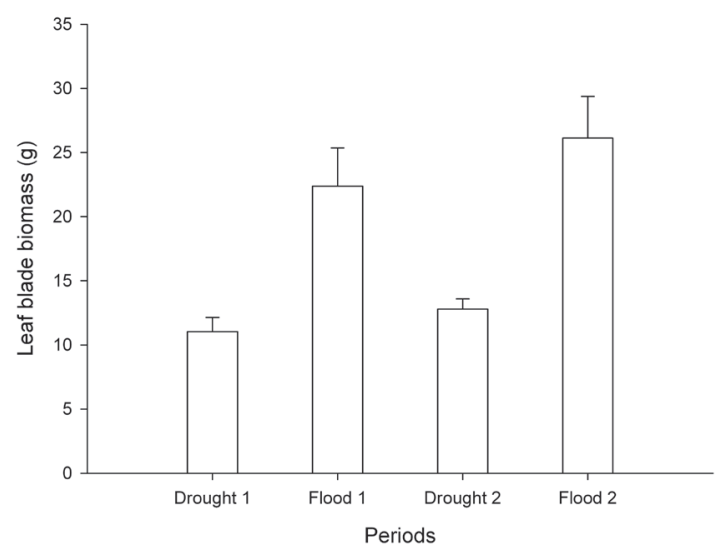

Figure 4. Leaf blade biomass during flood and drought periods in the Funil power plant reservoir. The plants invested more in leaves biomass during flood periods, which probably occurred in order to enhance the contact of the photosynthetically active areas with the atmosphere. 
$(t=43.86 ; p<0.001)$ (Figure 6). These results indicate that, during flood periods, Sagittaria montevidensis individuals produce bigger leaves. Despite the bigger leaves during flood periods, the total diameter was significantly higher in flood periods, when comparing the first drought and flood cycle (Period1) $(t=64.86 ; p<0.001)$ (Figure 7), and also when comparing the second drought and flood cycle (Period 2) $(t=98.76 ; p<0.001)$ (Figure 7). This result implies that there are bigger plants with shorter leaves during drought periods.

\section{Discussion}

Habitat physical characteristics have been long recognised as a main driver for macrophytes morphology, and a morphological approach holds value for the understanding of habitat functioning (Daniel et al., 2006). Changes in water level are cited as powerful inducers of plastic responses in aquatic macrophytes (Trémolières, 2004), but growth responses to flooding may be species-specific (Deegan et al., 2007; Luo and Xie, 2009) and, in the case of our study, S. montevidensis strongly responded to water level fluctuations between drought and flood periods. Increases in height of submerged parts of emergent macrophytes, as well as a higher biomass allocation to the aerial parts, are commonly adopted as growth strategies to deal with water level increase (Grace, 1989; Clevering and Hundscheid, 1998; Sánchez-Reyes et al., 2012). This holds true for our data set, since S. montevidensis showed a consistent pattern of increase in shoot height and leaf biomass during flood periods. This may signify an attempt to keep the photosynthetically active area above the water surface (Brandle, 1991; Armstrong et al., 1994), which will allow maintenance of carbon assimilation and photosynthesis rates.

Lorenzi (2000) reports that $S$.montevidensis can reach maximum heights of $1.5 \mathrm{~m}$. In our study we found plants reaching $1.8 \mathrm{~m}$ in the second flood period, suggesting great morphological plasticity with the water levels increase. Height increase through petiole elongation is necessary for the plant in order to avoid total submersion of S. montevidensis photosynthetic structures. This increase in height is a common response of aquatic plants to a rise in water level (Sorrell et al., 2002; Santos and Esteves, 2004; Macek et al., 2006; Paillisson and Marion, 2006) and is consistent with other results for Sagittaria species. Sagittaria lancifolia $\mathrm{L}$. responded to the increase in water level by increasing its leaf height (Howard and Mendelssohn, 1995), Sagittaria sagittifolia $\mathrm{L}$. tolerated prolonged submersion through the increase in the submerged parts length (Van den Brink et al., 1995), Sagittaria macrophylla also tolerated flood periods by increasing its aerial parts in order to allow their contact with the atmosphere (Sánchez-Reyes et al., 2012). Maintenance of the photosynthetic active surface was also the main point for Eleocharis sphacelata R. Br. survival when water level increased (Sorrell et al., 2002).

Sagittaria montevidensis also presented higher leaf biomass during flood periods, which is in accordance with other studies with macrophytes, such as Miscanthus

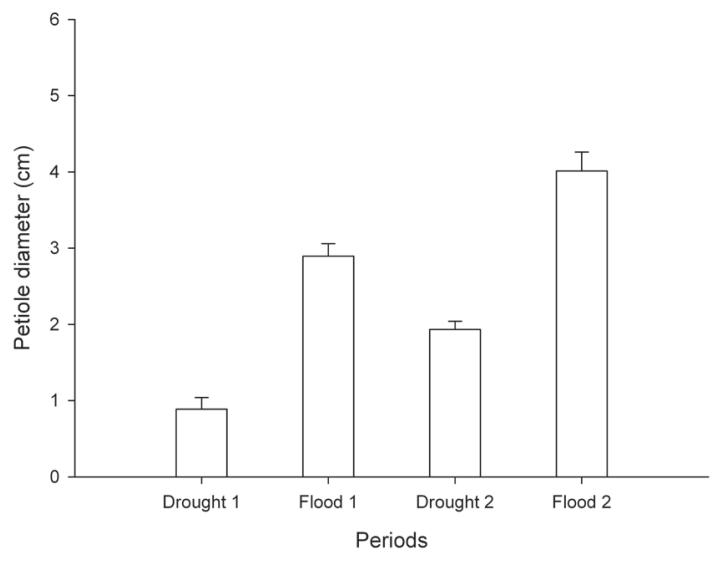

Figure 5. Petiole diameter during flood and drought periods in the Funil power plant reservoir. The plants presented bigger petioles during flood periods, which may represent a way to avoid submersion of the photosynthetically active areas.

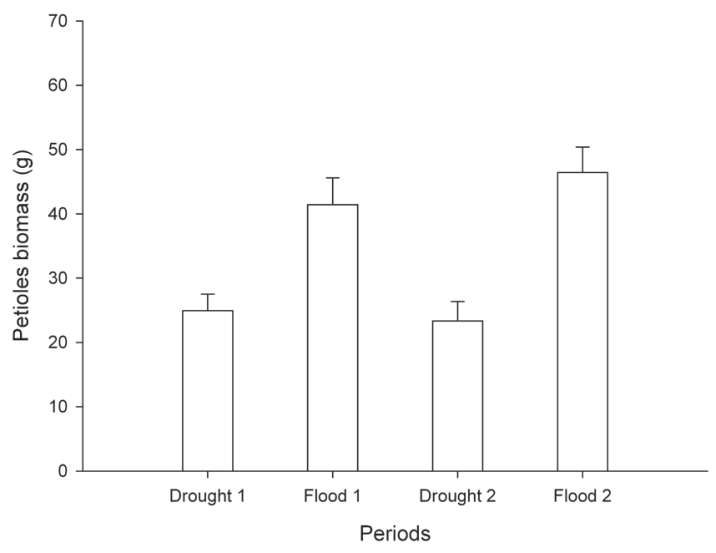

Figure 6. Petiole biomass during flood and drought periods in the Funil power plant reservoir. The plants presented more robust petioles during flood periods, which may represent a way to avoid uprooting and structural breaks due to a stronger water flow than in drought periods.

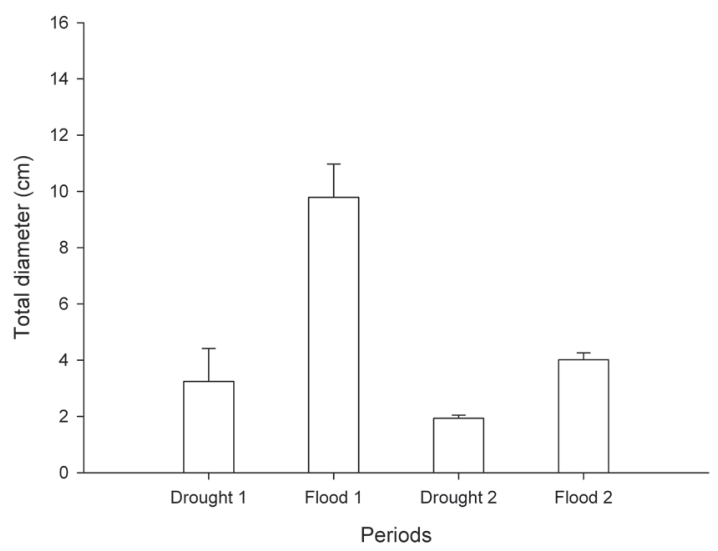

Figure 7. Total plant diameter during flood and drought periods in the Funil power plant reservoir. The plants presented higher diameters during flood periods showing more robustness during the periods when water flow is more intense and may drag the plants. 
sacchariflorus (Maxim.) Hackel, and Carex brevicuspis C.B. Clarke, that also produced leaves with higher biomass during flood periods (Pan et al., 2012). This may have allowed functional contact of submerged parts with the atmosphere, which may have improved gas exchange and photosynthetic processes (Gopal and Goel, 1993; Coelho et al., 2000). In our study, S. montevidensis invested in petiole elongation and in leaf biomass. This result can suggest that this species is very efficient in the use of available resources or that it has little resources demands, allowing investment in both processes.

Petiole diameter and biomass, and also the basal diameter of plants, were higher in flood periods, contrasting with our hypothesis. We expected that an increase in water level would generate decreases in petiole biomass, since in many emergent macrophytes aerial stems cavities are filled with a variety of lignified tissues that confer mechanic resistance to flexion. Therefore, an increase in the plant basal area and in petiole diameter would provide higher resistance to flexion at lower water levels, since in deeper areas, water would provide mechanical support for the plant parts (Sorrell et al., 2002). This may be related to the absence of histological differentiation of plant tissues under different water levels. Cassol et al. (2008) showed that increases in water levels did not lead to the synthesis of secondary cell walls. In our study, however, plants were submitted to a strong water flow during flood periods, which may have caused the investment in greater basal areas, petiole diameter and petiole biomass. Plants with lignified petioles present a higher resource investment in these tissues when submitted to adverse conditions, such as flood periods (Cooling et al., 2001). This investment could increase resistance to gas flow (Brix et al., 1992). We suggest that $S$. montevidensis invests in external lignification of its petioles in flood periods as occurs in other aquatic plant species, such as Phragmites australis (Cav.) Trin. ex Steud. (White and Ganf, 2002). Therefore, higher petiole diameter and consequently larger basal areas in the flood periods can provide larger resistance to break and uprooting caused by water flow forces that directly affect the rooted macrophytes (Schutten et al., 2005), as Egeria najas Planch., and Hydrilla verticillata (L. f.) Royle, for which higher flood levels were considered a potential disturbance driver, causing sediment moving and plant scouring (uprooting) (Sousa et al., 2010).

We conclude that $S$. montevidensis presents great morphologic plasticity in relation to water level. The most expressive increase in petiole length, associated to higher leaf biomass during flood periods, is a useful strategy, since it guaranteed contact of the aerial part of the plant with the atmosphere surface, optimising gas exchange and also photosynthetic processes. The increase in petiole diameter and basal plant areas in flood periods provided a higher stability and resistance to water flow forces for S. montevidensis. Plastic responses to the stress caused by water level increase allowed S. montevidensis survival and maintenance of its infestation potential in sediment banks.

\section{Acknowledgements}

It is with pleasure that we thank Maurício M. Petrúcio and Dayse L. M. C. Resende for their valuable comments and suggestions on early versions of this work and Lisiane Zanella and Ludmila Zambaldi for their help with the map. This work was supported by the Usina Hidrelétrica Funil - Consórcio Vale/Cemig.

\section{References}

ALPERT, P. and SIMMS, EL., 2002. The relative advantages of plasticity and fixity in different environments: when is the good for a plant to adjust? Evolutionary Ecology, vol. 16, no. 3, p. 285-297. http://dx.doi.org/10.1023/A:1019684612767.

ARMSTRONG, W., BRANDLE, R. and JACKSON, MB., 1994. Mechanisms of flood tolerance in plants. Acta Botanica Neerlandica, vol. 43, no. 4, p. 307-358. http://dx.doi.org/10.1111/j.1438-8677.1994. tb00756.x.

AROVIITA, J. and HÄMÄLÄINEN, H., 2008. The impact of water-level regulation on litoral macroinvertebrate assemblages in boreal lakes. Hydrobiologia, vol. 613, no. 1, p. 45-56. http:// dx.doi.org/10.1007/s10750-008-9471-4.

BALDWIN, AH. and MENDELSSOHN, IA., 1998. Effects of salinity and water level on coastal marshes: an experimental test of disturbance as a catalyst for vegetation change. Aquatic Botany, vol. 61, no. 4, p. 255-268. http://dx.doi.org/10.1016/ S0304-3770(98)00073-4.

BRANDLE, RA., 1991. Flooding resistance of rhizomatous amphibious plants. In JACKSON, MM., DAVIES, DD. and LAMBERS, H. (Eds.). Plant life under oxygen deprivation: Ecology, Physiology and Biochemistry. Hague: Sbp Academic Publishing Bv. p. 35-46.

BRIX, H., SORRELL, BK. and ORR, PT., 1992. Internal pressurization and convective gas flow in some emergent freshwater macrophytes. Limnology and Oceanography, vol. 37, no. 7, p. 1420-1433. http://dx.doi.org/10.4319/lo.1992.37.7.1420.

CASSOL, B., AGOSTINETTO, D. and MARIATH, JE., 2008. A. Análise morfológica de Sagittaria montevidensis desenvolvida em diferentes condições de inundação. Planta Daninha, vol. 26, no. 3, p. 487-496. http://dx.doi.org/10.1590/S0100-83582008000300003.

CHAGAS, GG., FREESZ, GMA. and SUZIKI, MS., 2012. Temporal variations in the primary production of Eleocharis acutangula (Cyperaceae) in a tropical wetland environment. Brazilian Journal of Botany, vol. 35, no. 3, p. 295-298. http:// dx.doi.org/10.1590/S1806-99592012000300008.

CLEVERING, OA. and HUNDSCHEID, MPJ., 1998. Plastic and non-plastic variation in growth of newly established clones of Scirpus (Bolboschoenus) maritimus L. grown at different water depths. Aquatic Botany, vol. 62, no. 1, p. 1-17. http://dx.doi. org/10.1016/S0304-3770(98)00081-3.

COELHO, FF., LOPES, FS. and SPERBER, CF., 2000. Densitydependent morphological plasticity in Salvinia auriculata Aublet. Aquatic Botany, vol. 66, no. 4, p. 273-280. http://dx.doi.org/10.1016/ S0304-3770(99)00084-4.

COOLING, MP., GANF, GG. and WALKER, KF., 2001. Leaf recruitment and elongation: an adaptive response to flooding in Villarsia reniformis. Aquatic Botany, vol. 70, no. 4, p. 281-294. http://dx.doi.org/10.1016/S0304-3770(01)00153-X. 
DANIEL, H., BERNEZ, I. and HAURY, J., 2006. Relationships between macrophytic vegetation and physical features of river habitats: the need for a morphological approach. Hydrobiologia, vol. 570, no. 1, p. 11-17. http://dx.doi.org/10.1007/s10750-006-0156-6.

DEEGAN, BM., WHITE, SD. and GANF, GG., 2007. The influence of water level fluctuations on the growth of four emergent macrophyte species. Aquatic Botany, vol. 86, no. 4, p. 309-315. http://dx.doi.org/10.1016/j.aquabot.2006.11.006.

DYNESIUS, M. and NILSSON, C., 1994. Fragmentation and flow regulation of river systems in the northern third of the world. Science, vol. 266, no. 5186, p. 753-762. http://dx.doi.org/10.1126/ science.266.5186.753. PMid:17730396

GIBSON, KD., BREEN, JL., HILL, JE., CATON, BP. and FOIN, TC., 2001. California arrowhead is a weak competitor in waterseeded rice. Weed Science, vol. 49, no. 3, p. 381-384. http://dx.doi. org/10.1614/0043-1745(2001)049[0381:CAIAWC]2.0.CO;2.

GOPAL, B. and GOEL, U., 1993. Competition and allelopathy in aquatic plant communities. Botanical Review, vol. 59, no. 3, p. 155-210. http://dx.doi.org/10.1007/BF02856599.

GRACE, JB., 1989. Effects of water depth on Typha latifolia and Typha domingensis. American Journal of Botany, vol. 76, no. 5, p. $762-768$. http://dx.doi.org/10.2307/2444423.

HOWARD, RJ. and MENDELSSOHN, IA., 1995. Effect of increased water depth on growth of a common perennial freshwater-intermediate marsh species in coastal Louisiana. Wetlands, vol. 15, no. 1, p. 82-91. http://dx.doi.org/10.1007/BF03160683.

IWANAGA, F. and YAMAMOTO, F., 2008. Effects of flooding depth and growth, morphology, photosynthesis in Alnus japonica species. New Forests, vol. 35, no. 1, p. 1-14. http://dx.doi. org/10.1007/s11056-007-9057-4.

LI, F., LI, Y., QIN, H. and XIE, Y., 2011. Plant distribution can be reflected by the different growth and morphological responses to water level and shade in two emergent macrophyte seedlings in the Sanjiang Plain. Aquatic Ecology, vol. 45, no. 1, p. 89-97. http://dx.doi.org/10.1007/s10452-010-9334-8.

LIMA, BV., SOARES, DJ. and BARRETO, RW., 2010. Inoculum density of Plectosporium alismatis, a potential mycoherbicide, in relation to control of the aquatic weed Sagittaria montevidensis. Tropical plant pathology, vol. 35, p. 236-240.

LORENZI, H.,2000. Plantas daninhas do Brasil. Nova Odessa: Instituto Plantarum.

LOWE, BJ., WATTS, RJ., ROBERTS, J. and ROBERTSON, A., 2010. The effect of experimental inundation and sediment deposition on the survival and growth of two herbaceous riverbank plant species. Plant Ecology, vol. 209, no. 1, p. 57-69. http:// dx.doi.org/10.1007/s11258-010-9721-1.

LUO, WB. and XIE, YH., 2009. Growth and morphological responses to water level and nutrient supply in three emergent macrophyte species. Hydrobiologia, vol. 624, no. 1, p. 151-160. http://dx.doi.org/10.1007/s10750-008-9689-1.

MACEK, P., REJMÁNKOVÁ, E. and HOUDKOVÁ, K., 2006. The effect of long-term submergence on functional properties of Eleocharis cellulose Torr. Aquatic Botany, vol. 84, no. 3, p. 251258. http://dx.doi.org/10.1016/j.aquabot.2005.11.003.

MAGILLIGAN, FJ. and NISLOW, HK., 2005. Changes in hydrologic regime by dams. Geomorphology, vol. 71, no. 1-2, p. 61-78. http://dx.doi.org/10.1016/j.geomorph.2004.08.017.
MARTIN, SB. and SHAFFER, GP., 2005. Sagittaria biomass partitioning relative to salinity, hydrologic regime, and substrate type: implications for plant distribution patterns in coastal Louisiana, United States. Journal of Coastal Research, vol. 211, p. 167-174. http://dx.doi.org/10.2112/02110.1.

OOKAWARA, R., SATOH, S., YOSHIOKA, T. and ISHIZAWA, K., 2005. Expression of $\alpha$-expansin and xyloglucan endotransglucosylase/ hydrolase genes associated with shoot elongation enhanced by anoxia, ethylene and carbon dioxide in arrowhead (Sagittaria pygmaea Miq.) tubers. Annals of Botany, vol. 96, no. 4, p. 693702. http://dx.doi.org/10.1093/aob/mci221. PMid:16051632

PAILLISSON, JM. and MARION, L., 2006. Can small water level fluctuations affect the biomass of Nymphaea alba in large lakes? Aquatic Botany, vol. 84, no. 3, p. 259-266. http://dx.doi. org/10.1016/j.aquabot.2005.10.004.

PAN, Y., XIE, Y., CHEN, X. and LI, F., 2012. Effects of flooding and sedimentation on the growth and physiology of two emergent macrophytes from Dongting Lake wetlands. Aquatic Botany, vol. 100, p. 35-40. http://dx.doi.org/10.1016/j.aquabot.2012.03.008.

PITT, WM., COTHER, EJ., COTHER, NJ. and ASH, GJ., 2004. Infection process of Plectosporium alismatis on host and non-host species in the Alismataceae. Mycological Research, vol. 108, no. 7, p. 837-845. http://dx.doi.org/10.1017/S0953756204000024. PMid: 15446718

POTT, VL. and POTT, A., 2000. Plantas aquáticas do Pantanal. Brasília: Embrapa.

R CORE TEAM, 2012. $R$ : a language and environment for statistical computing. Vienna: R Foundation for Statistical Computing. Available from: <http://www.R-project.org/>. Access in: 10 oct. 2011.

SÁNCHEZ-REYES, V., GÓMEZ, CZ., MANJARREZ, FJ. and WHITE-OLASCOAGA, L., 2012. Efecto del nivel de agua sobre el tamaño y biomasa foliar de Sagittaria macrophylla (Alismataceae). Interciencia, vol. 37, p. 775-781.

SANTOS, AM. and ESTEVES, FDA., 2004. Influence of water level fluctuation on the mortality and aboveground biomass of the aquatic macrophyte Eleocharis interstincta (VAHL) Roemer et Schults. Brazilian Archives of Biology and Technology, vol. 47, no. 2, p. 281-290. http://dx.doi.org/10.1590/S1516-89132004000200016.

SCHLICHTING, CD., 1986. The evolution of phenotypic plasticity in plants. Annual Review of Ecology Evolution and Systematics, vol. 17, no. 1, p. 667-693. http://dx.doi.org/10.1146/annurev. es.17.110186.003315.

SCHUTTEN, J., DAINTY, J. and DAVY, AJ., 2005. Root anchorage and its significance for submerged plants in shallow lakes. Journal of Ecology, vol. 93, no. 3, p. 556-571. http://dx.doi. org/10.1111/j.1365-2745.2005.00980.x.

SOUSA, WTZ., THOMAZ, SM. and MURPHY, KJ., 2010. Response of native Egeria najas Planch. and invasive Hydrilla verticillata (L.f.) Royle to altered hydroecological regime in a subtropical river. Aquatic Botany, vol. 92, no. 1, p. 40-48. http:// dx.doi.org/10.1016/j.aquabot.2009.10.002 .

SORRELL, BK., TANNER, CC. and SUKIAS, JPS., 2002. Effects of water depth and substrate on growth and morphology of Eleocharis sphacelata: implications for culm support and internal gas transport. Aquatic Botany, vol. 73, no. 2, p. 93-106. http://dx.doi.org/10.1016/S0304-3770(02)00011-6.

THARME, RE., 2003. A global perspective on environmental flow assessment: emerging trends in the development and application 
of environmental flow methodologies for rivers. River Research and Applications, vol. 19, no. 5-6, p. 397-441. http://dx.doi. org/10.1002/rra.736.

TIAN, J., PAUSCH, J., FAN, N., LI, X., TANG, Q. and KUZNYAKOV, Y., 2013. Allocation and dynamics of assimilated carbon in rice-soil system depending on water management. Plant and Soil, vol. 363, no. 1-2, p. 273-285. http://dx.doi.org/10.1007/ s11104-012-1327-z.

TRÉMOLIÈRES, M., 2004. Plant response strategies to stress and disturbance: the case of aquatic plants. Journal of Biosciences, vol. 29, no. 4, p. 461-470. http://dx.doi.org/10.1007/BF02712119. PMid:15625402

VAN DEN BRINK, FWB., VAN DER VELDE, G., BOSMAN, WW. and COOPS, H., 1995. Effects of substrate parameters on growth responses of eight helophyte species in relation to flooding. Aquatic Botany, vol. 50, no. 1, p. 79-97. http://dx.doi. org/10.1016/0304-3770(95)00452-6.

WHITE, SD. and GANF, GG., 2002. A comparison of the morphology, gas space anatomy and potential for internal aeration in Phragmites australis under variable and static water regimes. Aquatic Botany, vol. 73, no. 2, p. 115-127. http://dx.doi. org/10.1016/S0304-3770(02)00010-4.

WEBB, JA., WALLIS, EM. and STEWARDSON, MJ., 2012. A systematic review of published evidence linking wetland plants to water regime components. Aquatic Botany, vol. 103, p. 1-14. http://dx.doi.org/10.1016/j.aquabot.2012.06.003.

WOOTEN, JW., 1986. Variations in leaf characteristics of six species of Sagittaria (Alismataceae) caused by various water levels. Aquatic Botany, vol. 23, no. 4, p. 321-327. http://dx.doi. org/10.1016/0304-3770(86)90080-X.

XIE, Y., LUO, W., WANG, K. and REN, B., 2008. Root growth dynamics of Deyeuxia angustifolia seedlings in response to water level. Aquatic Botany, vol. 89, no. 3, p. 292-296. http://dx.doi. org/10.1016/j.aquabot.2008.03.003.

ZHANG, X., LIU, X. and DING, Q., 2012. Morphological responses to water-level fluctuations of two submerged macrophytes, Myriophyllum spicatum and Hydrilla verticillata. Journal of Plant Ecology, vol. 6, p. 1-7. 